\title{
Human Rights and Global Environment
}

\author{
Flora Pricilla Kalalo \\ Faculty of Law, Universitas Sam Ratulangi, Manado-Indonesia \\ flora.kalalo@unsrat.ac.id
}

Published: 31/08/2021

How to cite:

Gul. R., EL Nofely, M, O. Human Rights and Global Environment. Sociological Jurisprudence Journal. Volume 4 Issue 2. Page 105 - 113. https://doi.org/10.22225/scj.4.2.2021.105-113

\begin{abstract}
Human rights and the environment are interconnected and mutually reinforcing. The concern of a group of people for the environment is not enough because changes in an environment have an impact not only locally, but often globally. Therefore it can be said that in countries where there are many violations of human rights, environmental damage often occurs. What happened then was that the human right to have a healthy life (the right to a healthy environment) was violated or sidelined. In addition, development that is not controlled can result in human rights being violated. Regulations regarding human rights are not entirely related to environmental protection. However, if you pay attention, there are several articles in some of these provisions that can be used as a legal basis for taking various actions aimed at protecting the environment. On the other hand, regulation of environmental protection at the same time means respect for human rights, especially with regard to issues of the right to life, health problems, disturbance of their property to respect for indigenous peoples' rights.
\end{abstract}

Keywords: environment; human rights

\section{INTRODUCTION}

The relationship between human rights and the environment continues to be studied by experts, especially regarding how the protection of human interests is related to the rights to the environment affected by development activities. Other aspects related to human rights and the environment are the destruction and pollution of the environment and its impact on human rights. Related to the right to life, the right to economic, socio-cultural and civil and political rights. The disruption of the function of the environment is of course closely related to human rights because damage to the environment may have an impact on human life. From the two factors above, it can be seen that the right to a good and healthy environment is part of human rights that must be protected. In fact, environmental destruction occurs despite various rules that have been made to uphold human rights to the environment. Economic and business interests sometimes conflict with legal protection of the environment.

It has been nearly two decades of discussions on human rights and environmental issues. Some international environmental law experts see human rights as a way to protect the environment. Real economic actors and financial economy actors, in this case banking, have a strategic role in harmonizing and balancing each element of the Development Trilogy. This strategic role is mainly due to the main function of the bank as a vehicle for collecting and channeling public funds effectively and efficiently, which on the basis of economic democracy supports the implementation of national development in order to increase equitable distribution of development and its results, economic growth and national stability. towards increasing the standard of living of the people at large.

Development and the environment have been seen as two things that are always contradictory. The problem is, development pursued through industrialization often creates problems in the environmental sector in the form of environmental destruction and pollution.

M. Zaidun, stated that: 
"In this context, development politics cannot be separated from its siding with the industrial sector, because this sector is the prima donna and the backbone that is expected to be able to catch up with the third world countries from developed countries, in addition to aiming to improve the welfare of the people at large"(Zaidun, n.d.).

Contradictions between development and the environment are caused by the existence of parties whose rights are reduced. Toll road construction that carries out evictions on the grounds of land acquisition for public interest. In development, it is often business, political and project interests that are the main reasons so that people's rights as human rights are neglected. People who have lived and controlled inherited land for decades are sometimes marginalized and displaced by the policies of the authorities in the name of the public interest. This is a problem in protecting human rights and the environment in this world, including Indonesia.

It has been nearly two decades of discussions regarding the issue of human rights and the environment. Some international environmental law experts see human rights as a way to protect the environment. Even David Hunter et.al. say that these experts consider that "human right not only as model for the progressive development of international environmental law, but as potential independent tool for protecting the environment"(Hunter, Salzman, \& Zaelke, 2007).

This means that understanding and recognizing human rights also means protecting the environment as well as being used to achieve sustainable development, because recognizing and protecting human rights is a potential way to protect the environment.

The environment and human rights are interconnected and mutually reinforcing. Therefore it can be said that in countries where there are many violations of human rights, environmental damage often occurs. For example the case of the Yanomami Indians, the Huaorani community in Ecuador, the Amungme and Kamaro people in Irian Jaya.

In various cases, local people have to deal with the authorities (who sometimes use armed force) in exploiting natural resources, such as timber, gold and crude oil. Natural resources are then exploited by newcomers which results in damage to the local environment, on the other hand, local people who have lived for generations and at the same time use the same area as a source of livelihood eventually lose their livelihoods. As a result of this conflict, many rulers (who helped many businessmen to achieve what they wanted), for example, protests by Amungme and Kamaro residents demanding justice (for land that has been controlled by them from generation to generation) to migrants (ic PT. Freeport Indonesia which uses the land as its mining area). The population was then intimidated, detained, tortured and even killed by the businessmen assisted by ABRI (because the residents were considered rebels)(Bachriadi \& di Tengah Kelimpahan, 1998).

The problems surrounding the protection of human rights and the environment globally, namely how the correlation of the protection system built on human rights and the global environment today and how the effectiveness of the environmental protection system prioritizes the right of the people to enjoy a good and healthy environment as a human right.

\section{RESULT AND DISCUSSION}

\section{Relationship Between Environmental Problems and Human Rights}

Environmental problems arise as a result of the human desire to develop and build a better life. In the framework of human rights, this desire is based on the right to development. Many humans forget about environmental factors, in carrying out development, especially those related to ecosystem problems (humans and their environment have a relationship with each other and are cyclical). For example, to get acceleration in the hands, pesticides are used which function to destroy plant pests. However, what is forgotten is that basically every species also has the resistance to survive, so that the longer use of pesticides actually has a negative impact on human health.

What happened then was that the human right to have a healthy life (the right to a healthy environment) was violated or sidelined. In addition, development that is not controlled can result in human rights being violated. For example, waste from gold mining can cause pollution and / or damage to rivers so that river users cannot meet their daily needs(Bachriadi \& di Tengah Kelimpahan, 1998). 
Meanwhile, for most local communities, land and rivers are a source of life that are highly valued as their own mother, therefore if the place is damaged, the reaction of the local community will be very strong.

In dealing with local residents, often government officials and law enforcers are involved. Even worse, many local residents became victims and died. As happened to the people of Amungme, Irian Jaya as reported by KOMNAS HAM. According to KOMNAS HAM in Timika there were human rights violations which included discriminatory killings, torture and degrading treatment, illegal arrests and arbitrary detention, disappearances of people and destruction of property by security forces(Bachriadi \& di Tengah Kelimpahan, 1998).

On the other hand, several human rights activists criticized the actions of environmentalists. According to them, the actions of environmentalists (activists) who protect the environment too much, such as protecting biodiversity, have violated human rights to meet the needs of life. Fulfilling human needs that is done excessively or not thinking about carrying capacity results in environmental damage and pollution, which in the end, humans will also receive the impact. In other words, not protecting the environment will result in the implementation of several human rights(Hunter et al., 2007).

Various other problems that have occurred in various countries including Indonesia can be seen from the recent flooding that occurred in Jakarta in February 2005 as a result of uncontrolled development and littering in rivers.

Based on the explanation above, although there is still debate between environmental activists, it should be realized that the environment and human rights are interdependent, as stated by David Hunter, this relationship can be seen from two meanings:

"first, environmental protection may be cast as a means to the end of fulfilling human rights standards; and Second, the legal protection of human rights is an effective means to achieving the ends of conservation an enviromental protection".(Hunter et al., 2007)

If environmental protection is not implemented, it will end the fulfillment of human rights standards, or it can also be said that legal protection of human rights is one of the effective ways to conserve and protect the environment.

\section{Protection of Rights and the Environment}

Protection of Human Rights

Provisions regarding the protection of human rights (human rights) internationally were regulated before World War II. The first time the provision regarding human rights is the protection of individuals for diplomats and military (combatan). This protection is actually aimed at the state because diplomats are given the task of representing the state while the military is tasked with protecting the interests of the state from all threats from within and outside. Therefore actions that threaten their safety can be interpreted as actions that are a threat to the country itself.

After World War II, there were many changes in the structure of the international community which felt that the state respected and recognized human rights (not only for diplomats and military). This is influenced by the democratic system adopted by many countries. Based on the individual democracy system is an intensity that is free and equal (equal). To implement the rule of law in a democratic country that refers to justice and to become a state based on law, the state must also recognize individual honor as the basis of justice as stated in the opening of the Universal Declaration of Human Rights / 1948 (hereinafter referred to as the 1948 declaration which declared in the UN General Assembly in UN GA Res.217 A (III) UN Doc. A / 810, December 10, 1948).

In order to respect individual honor, the 1948 Declaration was established. The 1948 Declaration was the first international instrument to explicitly recognize individuals as subjects of international law but of course with restrictions. Based on this 1948 declaration, various special international treaties concerning human rights emerged, both universally and regionally.

\section{Universally}

The 1948 Declaration can also be said to be a follow-up to the provisions contained in the Charter of the United Nations (UN Charter), one of which aims (Article 1 paragraph 3) is to "promote and 
encouraging respect human rights and for fundamental freedoms for all without distinction as to race, sex, language, or religion "(Promote and encourage respect for human rights and for basic freedoms of all people regardless of race, sex, language or religion).

This objective is reinforced in the ECOSOC (The Charter of the Economic and Social Council) Article 62 paragraph 2, namely: "reccommendations for the purpose of promoting respect for, and observance of human rights and fundamental freedoms for all" (recommendations for the purpose of encouraging respect for, and the exercise of human rights and fundamental freedoms to all people).

This declaration was then followed by the adoption of the International Covenant on Civil and Political Rights (hereinafter referred to as the ICCPR) and the International Covenant on Economic, Social and Cultural Rights (hereinafter referred to as the ICESCR) through UN General Assembly Resolution No. 2000 A (XXI) on December 16, 1966.

The ICCPR and the ICESCR both regulate the recognition of individuals in their political and socioeconomic life. Article 1 paragraph 1 of the two conventions states that every nation has the right of selfdetermination which becomes the basis for every individual to obtain status in his political life and socio -economic life. In relation to the protection of political rights, every individual must be free from arbitrary actions by a government and free from government intervention. To protect individual rights to their socio-economic and cultural life, the government is obliged to provide a decent life for everyone by, for example, providing employment opportunities (to implement the right to work) or providing education as an implementation of protection against the right to education.

\section{Regionally}

Regional human rights arrangements can be found in American countries which were established at the 9th International Conference of American States in 1948, namely the America Declaration of the Rights and duties of Man (hereinafter referred to as the American Declaration). In this declaration it is explicitly recognized that "all men are born free and equal" (all people are born free and equal) and to protect this honor humans have the right to both their social, economic and political life without discrimination. In practice, however, what is contained in this declaration is difficult to adhere to as a whole. Sometimes in practice there is still discriminatory treatment between American citizens of white and black or colored American citizens. Violations of human rights can be brought before the Human Rights Commission (part of the Organization of American States / the OAS) and the Inter-American Court of Human Rights(Hunter et al., 2007).

In addition to the declaration established by the countries of America (Inter-America System), human rights are also recognized by European countries through The European Convention for the Protection of Human Rights and Fundamental Freedoms (hereinafter referred to as the European Human Rights Convention). Based on this Convention, a Human Rights Commission and a Human Rights Court for the European Community were established(Hunter et al., 2007) whose job is to provide protection of human rights for the people of Europe.

The next regional influence is the African Charter on Human and Peoples Rights (hereinafter referred to as the African Charter) which was established by the organization of African countries (The Organization of African Unity / OAU) on 27 June 1981 and entered into force on 21 October 1986(The University of Minnesota, n.d.). This Charter requires that each OAU member state recognizes the rights, obligations and freedoms set forth in the Charter and must include them in the regulations of each country (Part I, Chapter I, Article 1 of the Charter). These rights, obligations and freedoms must be granted without discrimination (Article 2) and everyone is seen as equal before the law (equal before the law) (Article 3). Through this Charter a Human Rights Commission was also established for OAU countries, which is obliged to promote human rights and the nation and ensure protection of the exercise of these rights (Part II, Chapter 1, Article 30).

From the various regional international agreements above, it can be concluded that protection of human rights has been recognized in various parts of the world and as a guarantee of human rights is implemented, a special commission is also formed on the protection of human rights. Unfortunately, ASEAN as one of the largest organizations in the world does not yet have a special agreement on human rights. 


\section{Protection of the Environment}

The various provisions regarding human rights above do not explicitly discuss environmental protection. However, if we pay attention to it, there are several human rights that are closely related to environmental issues, especially rights related to the third generation of human rights, namely solidarity rights. This right includes the right to a clean environment which can be divided into the right to live, the right to a decent life, the right to health and the right to freedom over property. What should not be forgotten is the protection of human rights which is closely related to the environment, namely protection of indigenous people / local communities.

\section{Protection of Life}

The right to life can be impaired due to damage or pollution to the environment which affects human health, for example what happened in the Chernobyl case which resulted in thousands of people dying or suffering lifelong disabilities due to radiation. The explosion of a nuclear reactor in Russia (formerly the USSR) which resulted in around 10 thousand people dying of cancer and around 7 thousand people who immediately died at the Mitino cemetery, Chernobyl (Kurniawan, 1996). In the ICCPR, article 6 paragraph 1 is recognized that "Every human being has the inherent right $t$ life. .No one shall be arbitrarily deeprived of his life "(Every human being has the right to live since birth, no one can simply lose his life).

Based on this verse, everyone has the right to live and no one up to the state can arbitrarily stop someone's life. This means that the state must also take various actions, or at least not be negligent, to protect human life. If it is related to environmental problems, environmental damage or pollution can result in the death of people, as has happened in various parts of the world due to the nuclear industry or pollution from various sources.

Such protection is affirmed in the Draft Declaration of Priciples on Human Rights and the Environment, 1994 (Part II Principle 5), hereinafter referred to as the 1994 Draft Declaration, which regulates that: "All persons have the right to freedom from pollution environmental degradation and activities that adversely affect the environment, treathen life ... within, across and outside national boundaries "(Everyone has the right to be free from environmental degradation, pollution and activities that damage the environment, threaten life inside, across and beyond -country boundaries).

Based on this principle, pollution must be overcome so that human life is maintained. The follow-up is to make various provisions in various countries that often require cooperation between countries, especially those that are transboundary in nature.

Protection of a healthy environment

The 1948 Declaration does not explicitly regulate the right to a healthy environment, but only states that "everyone has the right to a standard of living adequate for the health and well-being of himself and of his family, ..." ( Article 25) (Everyone must have the right to a satisfactory public environment in order to support its development) (Article 25).

Even though it does not explicitly say a healthy environment, but to get a life that is adequate for the health to show that everyone has the right to get a healthy life. To have a healthy life, of course, you have to protect the environment from damage and pollution.

In addition to the 1948 Declaration, article 7 of the ICESCR point $b$ states that the recognition of the right of everyone to healthy working conditions (... the right of everyone to enjoyment of just and favorable conditions of work ... (a) ... (b) safe and healthy conditions; ...) (... the right of everyone to enjoy various conditions ... (a) ... (b) .. conditions of safety and health). Healthy conditions are not only obtained at home but in the workplace, everyone has the right to a healthy environment. Can be used as a comparison is Article 24 of the African Charter which regulates "All peoples shall have the right to a general satisfactory environment favorable to their development." (Everyone should have the right to the general satisfaction of the environment for their development).

In the African Charter governed by All Peoples which denotes all nations which of course also includes every individual. This means that every individual has the right to a pleasant living environment.

A clean and healthy living environment or can be called an adequate living condition also includes 
the principles set out in the Stockholm Declaration Of the United Nation Conference on the Human Environment (Stockholm Declaration 1972) principle 1, namely: "Man has the fundamental right ... and adequate condition of life, in an environment of a quality ... "(Humans have fundamental rights ... and proper conditions of life, in an environmental quality). Principles 8 and 9 of the 1994 draft declaration also regulate the right of everyone to healthy living conditions, including at work.

The key to fulfilling this right is none other than the protection of the environment. In the end, humans will also enjoy a clean environment, free from pollution. This is also stated in principle 1 of the Stockholm Declaration ("... And he bears solemn responsibility to protect and improve the environment ...") (... and he was born to be responsible for protecting and advancing the environment).

Article 12 of the ICESCR states that: The states Parties to the present Covenant recognize the right to everyone to the enjoyment of the highest attainable standard of physical and the mental health. (Existing participating states recognize the right of everyone to the enjoyment of the highest attainable standard of physical and mental health).

It is everyone's right to be physically and mentally healthy. This is achieved through the protection of these rights. In order to achieve the fulfillment of this right, it is further stipulated that the state must take various actions to:

The improvement of all aspects of envorimental and industrial higyene; the prevention, treatment and control of epidemic, endemic, occupational and other diseases;

It is clear that in the ICESCR, apart from giving rights, it also regulates the obligations to be able to fulfill each of these rights by means of, among other things, improving the environment, especially due to industrialization.

Furthermore, Article 6 of the Stockholm Declaration stipulates that the state must take all measures to combat pollution. This is intended so that human health is maintained because pollution has a negative impact on human health. For example, respiratory infections / ISPA which often occur in areas covered with smoke due to forest fires or skin rashes suffered by residents living around polluted rivers. Another example is the Trail Smelter case, a case that happened to residents of the United States who for several years breathed dirty air (polluted) due to the activities of a fertilizer factory located in Canada which resulted in these residents suffering from nausea and respiratory illness. And also taken into consideration are the results of research at Cornell University, United States which found that constant (constant) noise from planes also has a negative impact on children's health and psychology (Hunter et al., 2007).

The results of research conducted by the Board of Health, Massachusetts USA (Hunter et al., 2007) is pollution due to reduced indoor air quality. Modern life that requires a lot of air conditioning or heating (heather) has resulted in many buildings being closed tightly without ventilation. The goal is that these two tools can work optimally. The results of the study concluded that in the absence of fresh air flow, air contamination occurs which causes health problems such as dizziness or air poisoning. The contamination comes from cigarette smoke, $\mathrm{CO} 2$ from human respiration, or chemical emissions from wall paint.

The Right To Be Free For Interference On One's Home And Property

Article 171 of the ICCPR regulates:

No One shall be subjected to arbitrary or unlawful interference with his privacy, family, home or.....'

Everyone has the right to the protection of the law againts such interference...

In addition, Article 8 of the European Convention on Human Rights regulates:

Everyone has the right to respect for his private and family life and...;

The shall be no interference by a public authority with this right except ... for the protection of health or morals, or for the protection of the rights and freedoms others.

What is meant by interference includes environmental disturbances, flooding from a dam, and weather changes due to the activities of a nuclear power center (PLTN) which will significantly affect personal life. This means that this disturbance can be said to be a violation of human rights. For 
example, the case of Lopez-Ostra vs Spain, 1994 (Hunter et al., 2007) which relates to emissions from toxic fumes originating from a tannery factory that violate an individual's right to use their property.

Protection of Indigenous People

There are many conflicts that occur between human rights and the environment related to problems of indigenous people. Clashes often occur between them and migrants who are often assisted by local law enforcement agencies. An example happened in Timika, between the Amungme Tribe and the Kamoro with PT Freeport who was assisted by local security forces, or between the Huaorani (one of the indigenous people of the Amazon) and the local government. The results of UN research through its research institute (The UN Research Institute for Social Development) estimated about 50 conflict incidents concerning ethnicity and social development. The majority of the triggers for the conflict are related to economic poverty and the struggle for resources that are increasingly scarce and actually used for their livelihoods (Bloch, 2001). The question is who are meant by indigenous people? In the ILO convention no. 169 concerning Indigenous People and Tribal People (hereinafter referred to as the 1989 ILO Convention) which was made in 1989 explains what is meant by indigenous / tribal people are:

Tribal Peoples in Independent countries whose sosial, cultural and economic conditions distinguish them from other sections of the national community, and whose status is regulated wholly or partially by their own costums or traditions or by special laws or regulations.

Based on the 1989 ILO Convention, indigenous people are a group of people who live in a country, but their economic, social and cultural conditions are different from people in other areas and in their lives they use their own customs. Therefore, it can be said that they have their own characteristic which is called in the 1989 ILO Convention as self-identification (Bloch, 2001). Besides having self identification, according to David Hunter (Hunter et al., 2007), The criteria for an indigenous population are they are a group of people who are easily attacked, disturbed, moved (within their territory), or exploited; has a long relationship with a certain area; hope to keep the differences they have.

Therefore indigenous people are:

Not a group that dominates nationally;

Have criteria for culture in a certain area;

From generation to generation in the area;

There are differences both socio-economic and cultural with other communities in the country;

Objectively different from the point of view, among others, language, race, spiritual culture;

Treated as indigenous in various regulations and policies.

If the above criteria are related to existing facts, it is true that indigenous people often suffer as a result of seizure of natural resources around their homes. What's worse, they are often accused of causing environmental degradation. For example, forest fires in the forests of Kalimantan, Sumatra (Indonesia) or other parts of the world (for example, rainforests in the Amazon, Brazil). In fact, they actually have more knowledge to protect their territory properly. For them, the land and all the resources contained in it is the source of their life, so they will treat it with care. For example, the attitude of the Amungme Tribe in Timika, Irian Jaya or the Huaorani Tribe in Ecuador in managing their residence with existing natural resources. The results of NGO Biome (Human Biosphere) research on 12 ethnic groups in East Kalimantan resulted in a conclusion that rural tribes have made efforts to prevent and control forest fires("Suku Pedalaman Lebih Paham Atasi Kebakaran Hutan," 2001).

To protect the rights of indigenous people, internationally it can be seen starting from the UN Charter which stipulates that every nation or individual has the same rights and the right to determine what is good for themselves (individual rights and self determination). Apart from that, the ICCPR and the ICESCR, Article 1 paragraphs 1 and 2 describe that based on self-determination they are also entitled to determine starting from their point rights up to their socio-economic and cultural life. It is also emphasized in Article 27 of the ICCPR that the rights of people of different ethnicities and belonging to minorities cannot be neglected. Including their right to use natural resources (Article 47 ICCPR).

In ILO Convention 169, which is a provision that directly addresses the rights of indigenous people, their rights related to environmental issues also govern. Their rights are as follows: 
Indigenous peoples have the right to improve their living and working conditions and are also entitled to have their health improved. For this reason, the Government (where they are located) must protect and take various preventive measures to protect the environment in which they live(Konvensi ILO 169, n.d.).

They have the right to utilize, regulate and conserve natural resources in their residence where they need them. If their territory is to be explored and exploited, they must be invited to negotiate for resettlement and they must also enjoy the benefits of these activities.

They have the right to workplaces that do not endanger their health, especially from the influence of pesticides or other toxic substance.

The provisions in ILO Convention 169 show that as workers, indigenous peoples must also be treated equally, including their right to enjoy all the natural resources they need. In addition to ILO Convention 169 which specifically regulates indigenous peoples, internationally a special draft has been made to regulate human rights and the environment, which specifically regulates principles relating to indigenous peoples' rights. These rights are:

Indigenous peoples have the right to land and natural resources contained therein;

Indigenous peoples have the right to maintain their traditional life, including obtaining guarantees for this;

Indigenous peoples have the right to get protection from various actions that damage and reduce the quality of the place where they live.

As a comparison can also be seen the Draft Declaration on the Right of Indigenous Peoples, 1993 especially Articles 25 - 30. The draft, as well as ILO Convention 169 specifically regulates indigenous peoples. Some of the rights of indigenous peoples which are regulated and related to the environment are as follows("Draft Declaration on the Right of Indigenous Peoples," 1993):

Maintaining spiritual relations with land, water and coast and all natural resources that have traditionally been controlled or used by them;

Increase and also utilize natural resources controlled by them by using their traditional methods / habits;

They have the right to restore land, territories and natural resources controlled by traditional means and if this is not possible they are entitled to fair compensation;

They have the right to conserve, restore and protect the environment in which they live;

They have the right to recognition of their intellectual property rights (traditional knowledge);

They have the right to obtain various information regarding the construction of their residence.

From the various regulations above, it can be concluded that the protection of the human rights of indigenous peoples and the environment (especially the environment in the interior) is closely related. This is related to the fact that various natural resources needed for human life are actually found in the residences of groups belonging to the category of indigenous peoples. Therefore, there are many conflicts that occur between natural resource managers and local people who also both need these natural resources, but with different interests. For indigenous peoples or local communities, natural resources are only needed for their daily needs, while for immigrants, natural resources are made into commodities of high value so that what happens is the migrants exploit natural resources maximally.

\section{III.CONCLUSION}

The correlation of human rights protection is very strong and synergy is related to realizing the right to a good and healthy environment for humans. With the pace of development, human rights to a healthy environment are often neglected because of business, political and project interests. Environmental destruction and pollution always compromises the rights of the weak people who are categorized as vulnerable groups to human rights violations, such as the poor, women and children. In an effort to enforce environmental laws globally, the law must create a balance between interests, development, human rights and the environment. If this does not happen and runs independently, the damage and pollution to the environment will be even greater and the people who are sacrificed due to environmentally oriented development activities will increase.

The effectiveness of the protection of human rights and the environment will be realized if the state as the authority in the implementation of development always puts forward the principle of the public interest. This public interest is not the interest of the authorities or the interests of political groups but the interests of the people to enjoy a good and healthy environment. River pollution, eviction and neglect of 
environmental damage and environmental pollution by the government is a global challenge for upholding environmental laws and protecting human rights.

For this reason, comprehensive policies and arrangements are needed to ensure a balance between development and protection of human rights globally so that the principles of sustainable development will be realized and the earth is saved.

\section{References}

Bachriadi, D., \& di Tengah Kelimpahan, M. (1998). Pelanggaranpelanggaran HAM pada Industri Pertambangan di Indonesia. ELSAM, Jakarta.

Bloch, A. C. (2001). Minorities and Indigenous People. Netherland: Kluwer International and Martinus Nijhoff.

Draft Declaration on the Right of Indigenous Peoples. (1993).

Hunter, D., Salzman, J., \& Zaelke, D. (2007). International environmental law and policy (Vol. 516). Foundation Press New York.

Konvensi ILO 169.

Kurniawan, I. (1996). Pembangunan PLTN: demi kemajuan peradaban?: sebuah bunga rampai. Yayasan Obor Indonesia.

Suku Pedalaman Lebih Paham Atasi Kebakaran Hutan. (2001). Kaltim Post.

The University of Minnesota. (n.d.). No Title.

Zaidun, M. (n.d.). Amdal Sebagai Piranti Efektif Bagi Upaya Pengendalian Pencemaran Industri. Artikel Pada Jurnal Hukum Lingkungan Tahun II Nomor, 1. 